\title{
Proses Bisnis Organisasi dalam Business Process Modeling Foundations
}

Oleh :

\author{
Tarmin Abdulghani \\ Gede Agung Ary Wisudiawan
}

\begin{abstract}
Abstrak
Dalam perkembangan dunia IT saat ini, sehingga pemakain teknologi terbaru bisa dijadikan suatu keharusan dalam sebuah perusahaan. Perusahaan yang berkembang dan sedang mengimplementasikan teknologi baru bagi perusahaan diharuskan membangun atau mengembangkan proses bisnis baru yang sesuai dengan teknologi tersebut.

Tetapi tidak banyak yang bisa dilakukan untuk membuat agar proses bisnis dalam perusahaan tersebut dapat berjalan secara efektif dalam proses pengembangannya. Sehingga harus ada acuan yang bisa digunakan dalam mengembangkan proses bisnis agar menjadi efektif.
\end{abstract}

Keywords: proses bisnis, business process modeling foundations, process management life cycle.

\section{PEMBUKAAN}

Dengan adanya globalisasi, manajemen yang efektif dari sebuah proses bisnis suatu organisasi menjadi bertambah penting. Beberapa faktor seperti

- Kenaikan frekuensi dari pemesanan barang

- Kebutuhan akan transfer informasi yang cepat

- Pembuatan keputusan yang cepat

- Kebutuhan untuk beradaptasi terhadap permintaan

- Banyaknya kompetitor dari luar negeri

- Kebutuhan untuk daur hidup yang lebih pendek

Sehingga sangatlah diperlukan perencanaan sebagai dasar untuk melakukan perubahan atau pembuatan proses bisnis. Maka pada makalah ini akan dibahas bagaimana dasar dari permodelan proses bisnis dengan menggali pemikiran yang masih bersifat konsep dan selain itu juga akan diperkenalkan beberapa jeniss dari permodelan proses bisnis, yakni fungsi fungsi permodelan, proses, data, organisasi dan operasi. 


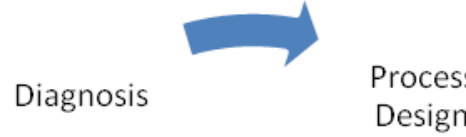

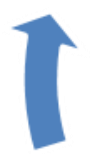

Process Enactment
Design

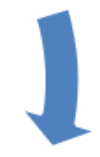

System Configuration
- Process design : pada tahap ini, segala dokumen yang bersifat terbuat kertas yang berguna pada proses bisnis akan dibuat secara digital (digitalisasi) dan dimasukkan ke dalam Business Process Management System (BMPS).

- System configuration : pada tahapan ini, dimana sebuah BPMS dikonfigurasi dan ditempatkan sesuai edngan struktur system. Pada tahapan ini akan berat pada bagian standarisasi dari arsitektur IT yang bermacam - macam.

- Proses Enactment : permodelan proses bisnis secara elektronik akan dibuat dalam BPMS engine, standarisasi eksekusi akan emndominasi tahapan ini.

- Diagnosis : memberikan analisa yang tepat menggunakan beberapa bantuan software sehingga dapat meningkatkan dan mengevaluasi keadaan "Bottle Neck"

\section{Conceptual Model and Terminology}

Proses bisnis terdiri dari aktifitas - aktifitas yang dikordinasikan untuk mencapai beberapa tujuan bisnis. aktifitas - aktifitas ini bisa berupa aktifitas sistem, aktifitas tatap muka user interface atau aktifitas manual. aktifitas manual tidak dapat didukung oleh sistem informasi. sebagai contoh aktifitas manual adalah memberikan sebuah bingkisan untuk rekan bisnis.

Aktifitas user interface (tatap muka pengguna )sudah selangkah lebih maju: ada beberapa aktifitas yang dikerjakan oleh para pegawai dengan keilmuan khusus atau sudah menggunakan sistem informasi. Disini tidak terdapat aktifitas fisik sebagai contoh dari sebuah aktifitas interaksi manusia adalah memasukkan data pada sebuah klaim asuransi dalam sebuah lingkungan call centre. Sejak digunakannya sistem informasi untuk mengerjakan aktifitas tersebut, maka aplikasi dengan berbagai tatap muka harus digunakan dengan tepat agar dapat bekerja secara efektif. Aplikasi tersebut haruslah dihubungkan dengan sistem aplikasi backend yang dapat menyimpan data yang 
dimasukkan dan membuatnya dapat digunakan untuk kebutuhan di masa mendatang. Beberapa aktifitas yang diselenggarakan selama pembuatan dari sebuah proses bisnis pada dasarnya besifat manual, tetapi seiring keadaan yang berubah maka dimasukkanlah proses bisnis yang bersifat manual tersebut kedalam sebuah sistem manajemen sebuah proses bisnis yang dikerjakan oleh alat - alat dari aktifitas tatap muka pengguna.

Aktifitas dari sistem tidak melibatkan manusia, semua itu dikerjakan dengan menggunakan sistem informasi. Sebagai contoh adalah sebagai berikut ada sebuah aktifitas sistem yang menerima informasi stok dari sebuah aplikasi broker atau mengecek neraca dalam sebuah proses perbankan. Hal ini dapat diasumsikan bahwa parameter yang aktual sangat dibutuhkan pada saat permohonan itu dibuat. Jika seseorang menyediakan informasi ini, hal ini disebut sebuah aktifitas antar pengguna. Kedua tipe dari aktivitas membutuhkan akses kepada reaksi dari sistem perangkat lunak. Bagian-bagian yang berbeda dari sebuah proses bisnis dapat digambarkan dalam sebuah alur kerja workflow. Sebuah manajemen system workflow dapat memastikan bahwa aktivitas dari sebuah proses bisnis sudah dilakukan dalam urutan yang benar, dan bahwa sistem informasi tersebut ikut didalamnya untuk merealisasikan fungsionalitas dari bisnis. Hubungan antara proses bisnis dan workflow ditunjukkan dengan sebuah hubungan antar masing-masing kelas. Workflow tidaklah sebuah subclass dari proses bisnis tetapi merupakan hubungan antara proses bisnis tersebut.

\section{ABSTRACTION CONCEPTS}

Untuk menggambarkan kompleksitas dalam manajemen proses bisnis, beberapa konsep abstrak akan diperkenalkan. Sebuah konsep abstrak dalam ilmu komputer adalah mebedakan masing - masing level dari permodelan, dari level bagian terbawah instance ke level model, kemudian ke level metamodel, dan dinotasikan dengan abstraksi yang horisontal. Agregasi dapat juga digunakan untuk mengatasi kompleksitas dan memotivasi tipe dari abstraksi yang lainnya. Pada abstraksi dengan level yang lebih tinggi, elemen yang jamak dari sebuah abstraksi pada level yang lebih rendah dapat dikelompokkan dan digambarkan dengan sebuah artefak tunggal. Contohnya, sebuah kumpulan dari aktivitas fungsional dapat dikontribusaikan ke sebuah fungsi bisnis pada level yang lebih tinggi

\section{Horizontal Abstraction}

Sepanjang garis dari setiap level abstraksi digambarkan oleh Object Management Group, metamodel level, model level dan instance level. Instance level menggambarkan entitas dasar yang ada dalam proses bisnis. Untuk mengatur kompleksitas dari skenario proses bisnis, maka digambarkanlah kumpulan dari masing - masing instance yang memiliki entitas yang serupa dan diklasifikasikan dalam model level.

Dalam memodelkan objek sekumpulan entitas yang serupa akan dikelompokkan oleh sebuah class. 
Dalam memodelkan data menggunakan pendekatan entity relationship, sekumpulan entitas yang serupa akan dikelompokkan menjadi sebuah kumpulan entitas. Hubungan yang serupa yang terjadi antara kumpulan entitas tersebut akan di gambarkan dengan sebuah kumpulan hubungan (relationship). Model yang digambarkan dalam metamodel akan diasosiasikan dengan notasi -notasi, dengan menggunakan simbol notasi dasar. Seperti contoh dalam petrinet. Dalam memodelkan data, Entity Relationship metamodel mendefinisikan tipe - tipe entitas, relationship, dan hubungan diantaranya. Notasi dari Entity Relationship metamodel adalah bujur sangkar untuk menggambarkan tipe entitas, wajik untuk menggambarkan tipe relasinya dan masing - masing entitas akan dihubungkan menggunakan garis.

\section{Vertical Abstraction}

Dalam vertical abstraction yang menjadi pusatnya adalah process modelling, dimana akan memiliki beberapa subdomain. Ada beberpaa subdomain yang biasanya digunakan dalam vertical abstraction seperti function modelling, data modelling, organization modelling dan modelling dari teknologi IT. selain beberapa subdomain tersebut bisa juga ditambahkan subdomain lain yang dianggap penting dan relevan dengan proses bisnis.

Function Modelling memberi informasi unit kerja apa saja yang digunakan dalam konteks proses bisnis, spesifikasi dari setiap level yang harus diselesaikan. Biasanya dikerjakan oleh karyawan dengan keahlian khusus dan dibantu oleh sistem informasi.
Data modelling sangatlah penting keberadaanya karena keputusan yang dibuat selama sebuah proses bisnis dijalankan tergantung beberapa nilai dari data yang ada. Sehingga kebergantungan data antara kebutuhan dalam aktifitas proses bisnis akan dimasukkan kedalam sebuah desain proses yang memastikn fungsi selalu mendapatkan data yang diperlukan untuk menjalankan fungsi tersebut.

Sedangkan organization modelling menggambarkan struktur organisasi dari sebuah perusahaan. Dimana aktivitas dalam proses bisnis dapat diasosiasikan dengan menggunakan aturan yang spesifik atau dapat digambarkan sebagai departemen dalam organisasi.

Sedangkan modelling teknologi IT berguna karena beberapa aktivitas dalam sebuah proses bisnis akan dikerjakan dengan bantuan atau menggunakan sistem informasi. Bagaimana sistem informasinya, hubungan, dan pendekatan dengan bahasa pemrogramanya yang dibutuhkn untuk menggambarkan fungsionalitas sistem informasi dalam suatu perusahaan. Sehingga perusahaan tersebut dapat berjalan dengan baik dalam mencapai tujuannya.

\section{BUSINESS FUNCTIONS TO BUSINESS PROCESS}

Bagian dari aktivitas perusahaan yang memiliki fungsi bisnis salah satunya adalah value chain. Dimana value chain ini terdapat dari level tinggi dalam organisasi yang jika dipecah lagi ke bawah maka akan dapat diperkecil sampai ke dalam fungsi - fungsi kecil yang sudah detail dari sebuah proses 
bisnis. Dekomposisi funsional tersebut tertinggi dari agregasi. Dimana setiap sistem adalah salah satu teknik dari pemilihan. berisikan beberapa value chains, yang Sebagian dekomposisi fungsional dapat karakteristiknya digambarkan dengan class dilihat dalam gambar berikut, dimana diagram yang ada di sisi kirinya. sebuah sistem menggambarkan level
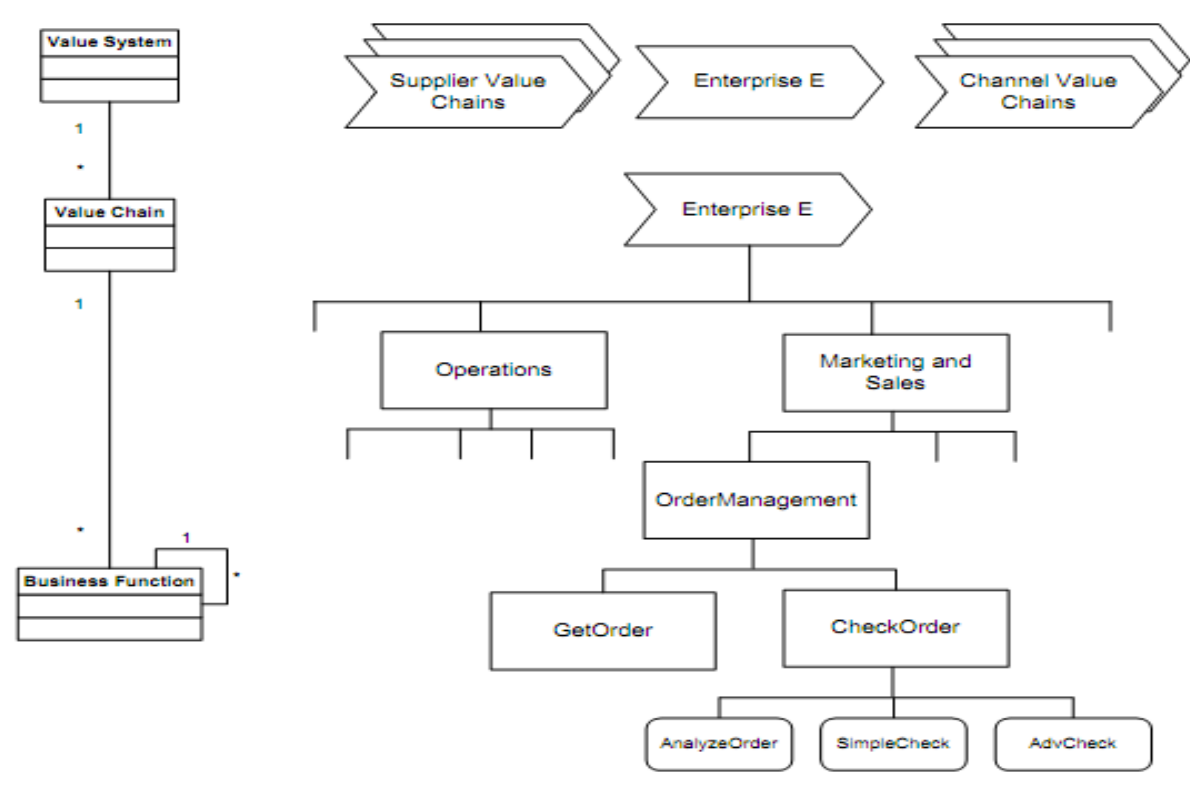

Ada beberapa syarat dalam penggambaran dekomposisi fungsional yaitu

- Fungsi bisnis akan digambarkan menggunakan persegi panjang

- Selama fungsi dari bagian terkecil tersebut digambarkan dengan bujur sangkar yang memiliki pojok yang tumpul.

Dekompsosisi fungsional digunakan sebagai langkah awal dalam penggambaran usaha dasar pada bisnis proses. Operasional pada proses bisnis adalah dimana aktivitas aktivitas satu dengan yang lainnya saling berelasi. Pada prinsipnya, merelasikan fungsi ke proses bisnis dapat diaplikasikan untuk bagian - bagian yang terkecil dari fungsi bisnis.

Contohnya adalah sebagai berikut dimana terdapat fungsi bisnis untuk mendatangkan logistic dan operasi. Pada fungsi bisnis ini sangat terlihat fungsionalitasnya dari setiap level, tidak ada fungsi bisnis dalam setiap urutannya yang dapat dikerjakan dengan mudah. Dalam keadaan dimana ada operasi dalam fungsi bisnis yang memesan material tambahan, kemudian ada aktivitas yang melakukan pemesanan secara riil. Dengan operasi tersebut sebuah pesanan internal dibuat dan dikirim ke bagian kedatangan logistic. Kemudian apabila pesanan sudah tiba, bahan mentah disediakan untuk melakukan operasi. Ada kasus dimana bahan mentah dalam bagian pabrik maka sebuah pesanan eksternal akan dibuat dan dikirimkan kepada pemasok bahan mentah tersebut. 


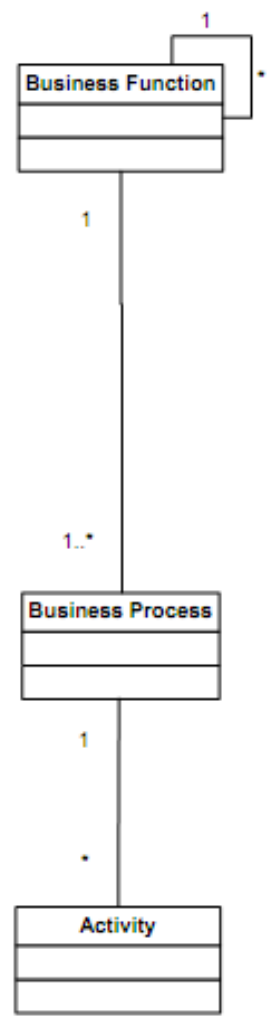

\section{Activity Model and Activity Instance}

Fungsi bisnis memberikan sebuah high-level, coarse-grained representasi dari pekerjaan yang ada dalam perusahaan. Dalam penjelasan berikut akan dijelaskan bagaimana aktivitas dapat digambarkan. Sebelumnya harus diketahui beberapa hal seperti activity model yaitu gambaran dari sekelompok aktivitas yang kecil, dan dianalogikan ke sebuah model proses yang menggambarkan sebuah kumpulan proses kecil dengan struktur yang sama. Selama model proses secara tipikal diekpresikan dalam notasi graph-like, model aktivitas dapat diekpresikan dalam bentuk yang berbeda.

Instance dari aktivitas menggambarkan pekerjaan actual yang dilakukan selama proses bisnis dan menggambarkan unit kerja yang actual juga. Dan perlu diingat setiap instance dari aktivitas selama masa aktifnya dapat memiliki status yang berbeda dan dapat digmbarkan oleh sebuah diagram state transition. Status sebuah instance dari aktivitas diadopsi selama masa hidup dapat digambarkan sebagai berikut : 


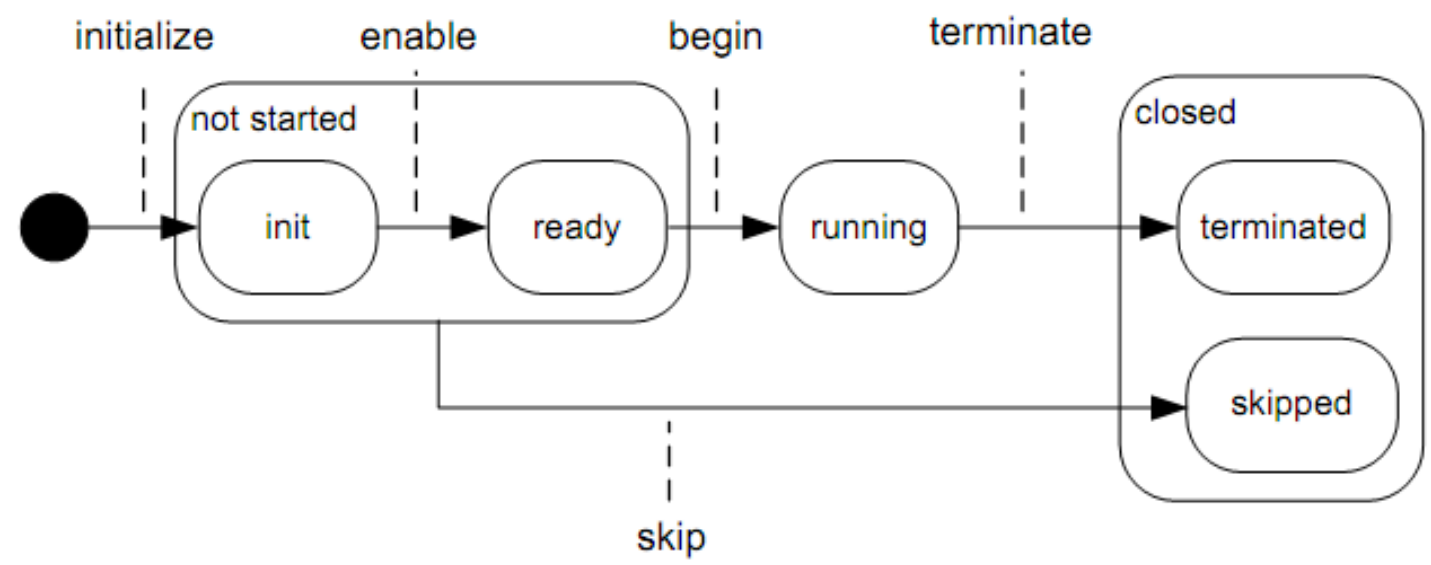

- Ketika instance tersebut dibuat dan akan memasuki status init,

- Dengan meng enabled kan state transistion maka aktivitas instance tersebut masuk ke dalam status ready.

- Jika ada sebuah instance dari aktivitas yang khusus tidak diperlukan, kemudian instance dari aktivitas tersebut dapat dilewati, digambarkan dengan sebuah status skip yang mulanya dari status not started menjadi status skipped.

- Dari status ready aktivitas instance tersebut dapat digunakan untuk memulai transisi status untuk ememasuki status running.

- Ketika instance dari aktivitas sudah selesai mengerjakan apa yang dikerjakannya maka status akan berubah menjadi terminated.

- Dan akhirnya apabila status berisikan salah satu diantara terminated atau skipped maka selanjutnya statusnya akan closed.

\section{Process Model and Process Instance}

Proses bisnis terdiri dari sebuah kumpulan aktivitas yang berelasi yang mana saling berkoordinasi untuk mengeksekusi dan berkontribusi untuk merealiasasikan sebuah fungsi bisnis dalam sebuah lingkungan teknikal dan organisasional. Proses bisnis diwakilkan kembali oleh model proses bisnis. Sejak bagian ini berkonsentrasi pada mengatur bagaimana mengeksekusi aktivitas, tidak memperdulikan lingkungan teknikal dan organisasional dari proses bisnis, aturan dari model proseslah yang digunakan.

Dalam aturannya untuk mengekpresikan model dari proses, maka dibutuhkan sebuah notasi di dalam tempat tersebut yang menyediakan notasional elemen - elemen untuk konseptual elemen metamodel dari proses. Jika metamodel tersebut memiliki sebuah konsep yang disebut model aktivitas, maka dibutuhkan sebuah notasional elemen untuk mengekpresikan model -model aktivitas. Sebuah notasi proses diasosiasiakan dengan level pada metamodel proses dan dengan level model proses. Setiap model proses di dalam sebuah notasi proses diasosiasikan dengan metamodel proses yang menerangkan model proses. 


\section{Process models}

Daripada menjadi konstruksi model yang komplit, focus dari bagian ini adalah bagaimana menyediakan sebuah metamodel proses yang digambarkan dengan baik sehingga dapat digunakan untuk menjelaskan komponen inti dari beberapa metamodel proses. Beberapa hasil dari permodelan dimulai dengan mengidentifikasikan konsep utama yang dibutuhkan untuk menjelaskan kembali. Dalam metamodeling, konsep untuk menjelaskan kembali tersebut adalah model - model. Beberapa model yang diidentifikasikan sebagai konsep dalam metamodel adalah sebagai berikut :

- Process Model : sebuah proses model menggambarkan sebuah blue print dari sebuah kumpulan instance proses dengan struktur yang sama. Model proses ini memiliki hirarki dua level, jadi setiap model proses terdiri atas sebuah kumpulan dari model aktivitas.

- Edge : adalah pinggiran langsung yang digunakan untuk mengekpresikan hubungan antara nodes dalam sebuah model proses.

- Node : digambarkan berupa titik, dimana dalam sebuah proses model dapat digunakan untuk menjelaskan sebuah model aktivitas, sebuah model even, atau sebuah model gateway.

- Activity models : adalah model aktivitas yang menjelaskan unit kerja yang berguna dalam sebuah proses bisnis. Seitap model aktivitas dapat muncul sekali saja dalam sebuah model proses.

- Events models : adalah model even yang menangkap peristiwa dari status yang erlefan pada sebuah proses bisnis. Instances proses diawali dan diakhiri dengan even, jadi model proses beraswal dan berakhir dengan model even.

- Gateway models : gerbang gateway digunakn untuk mengekspresikan konstruksi dari alur control, termasuk sekuen seperti simbol split dan join.

Setiap model proses berisikan elemen elemen pada level model, sebagai contoh model aktifitas. Instances dari proses terdiri dari instances aktivitas. Level model dan instance level tidak hanya berisikan aktivitas saja, tetapi juga event dan gateways. Sebagai contoh, even untuk mengawali di dalam sebuah aturan model proses dimana setiap instances proses memulai dengan sebuah instances even start. Sejak event adalah didefinisikan sebagai entitas singular (bentuk tunggal), instance event juga dipanggil event.

Aliran control didalam model proses digambarkan dengan model gateways. Sama seperti aktivitas dan events, gateways digambarkan dalam model proses dengan model gateways. Hal ini sangat berguna karena setiap mdoel gateway dapati dugunakan pada waktu yang berbeda dalam 
instance proses yang sifatnya memberi, contohnya jika ada yang merupakan bagian dari perulangan. Peristiwa yang berbeda dapat memiliki property yang berbeda juga. Setiap node diasosiasikan dengan lebih dari satu edge. Type dari nodesyang berbeda digambarkan dengan relasi generalisasi. Model aktivitas merefleksikan unit kerja yang akan bekerja, model event menggambarkan kejadian dari status yang relevan untuk proses bisnis dan model gateway menggambarkan kendala dalam mengeksekusi suatu aktivitas seperti node split dan join. Setiap aktivitas seperti dari sebuah gateway yang bersifat member

aktivitas model, event dan gateway memiliki hanya sebuah edge yang masuk dan keluar. Dan setiap proses dimulai dengan tanda starts hanya oleh satu event. Oleh karena itu, event yang berbeda data dapat tidak memiliki edge yang masuk (initial event) atau edges yang keluar (final events). Model Gateway menggambarkan alur control dmana dapat bertindak sebagai node atau join split tetapi tidak bisa keduanya. Oleh karena itu setiap model gateway dapat memiliki beberapa edge yang keluar (split gateway) ataupun yang masuk (join gateway).

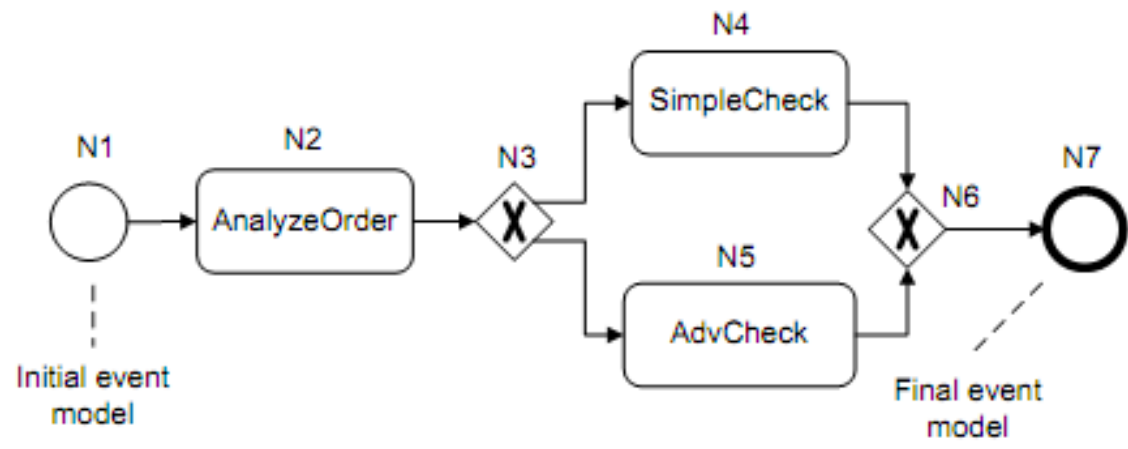

Dari gambar di atas dapat diartikan sebagai beriikut :

- Node pada model event digambarkan dengan lingkaran, sedangkan final atau akhir dari suatu event digambarkan dengan lingkaran dengan garis yang tebal.

- Model aktivitas digambarkan dengan persegi panjang dengan pojokan yang melingkar.

- Model gateway digambarkan dengan wajik.

\section{Process instance}

Instance proses berisikan beberapa instance dari aktivitas seperti instance activity, event dan gateway. Antara satu instance aktivitas dengan instance aktivitas yang lainnya dapat terhubung dengan menggunakan relationship dalam model proses. Ada beberapa tambahan class di dalam instance proses seperti sebuah generalisasi dari instance aktivitas, event dan gateway. Beberapa aturan dalam menetapkan model yang berisikan process instance dan process model

- Setiap instance proses diasosiaikan dengan tepat satu model proses, 
setiap proses model diasosiasikan dengan beberapa instance proses.

- Setiap instance proses disusun oleh beberapa instance aktivitas, event dan gateway instances.

- Setiap instance aktivitas diasosiasikan tepat dengan satu model aktivitas, dalam kasus perulangan sebuah aktivitas model dapat diasosiasikan dengan beberapa instances aktivitas.

- Setiap event diasosiasikan tepat dengan satu model event.
- Setiap gateway instances diasosiasikan tepat dengan satu gateway model

- Sebuah model aktivitas yang bergantung pada sebuah cabang yang tidak digunakan selama sebuah instance proses khusus tidak diasosiasikan dengan instance aktivitas yang lain dan akan ditunjukkan menggunakan tanda asosiasi * yang memperbolehkan asosiasi kosong.

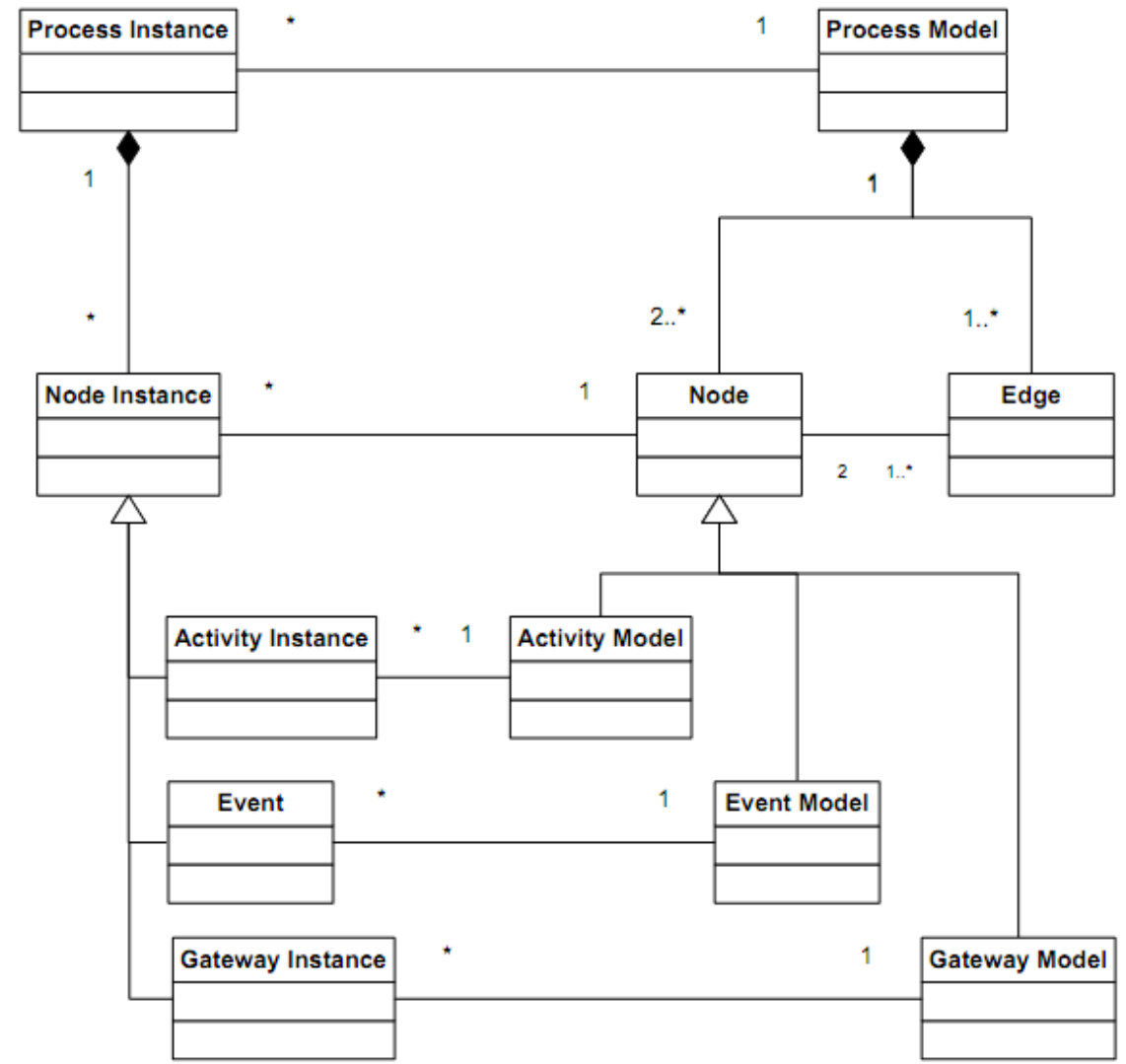

\section{Process Interactions}

Proses bisnis merupakan salah satu bagian dari sebuah organisasi, dimana dalam proses bisnis itu terdapat interaksi yang penting antara satu bagian dengan bagian yang lainnya. Hubungan interaksi antar bagian tersebut sangatlah penting untuk 
digambarkan agar mudah dalam mengerti suatu proses bisnis.

Dalam menggambarkan suatu interaksi antar bagian dalam suatu organisasi untuk menjalankan sebuah proses bisnis dapat menggunakan event diagram. Event diagram ini berisikan masing - masing bagian yang saling berinteraksi. Masing - masing bagian tersebut memiliki aturan aturan yang harus dilewati untuk melakukan sebuah proses bisnis. Dalam melakukan aturan tersebut tidak jarang suatu bagian membutuhkan sebuah interaksi dengan bagian lain, untuk berkomunikasi dengan bagian lain maka digunakanlah sebuah metode pengiriman dan penerimaan pesan. Pesan tersebut dibuat sesuai dengan kebutuhannya. Kemudian dikirimkan ke salah satu aturan dari bagian lain yang sesuai untuk menerima pesan tersebut. Dilanjutkan dengan mengolah pesan yang diterimanya tersebut dari bagian pengirim.

\section{Modelling Process data}

Proses bisnis beroperasi pada data, menggunakan data yang benar baik dari penggambaran data awal, kemudian type dari data dan ketergantungan data antara aktivitas dari sebuah proses bisnis yang diproses oleh sebuah system manajemen proses di dalam sebuah posisi untuk mengontrol transfer dari data yang dibutuhkan. Dalam melakukan permodelan data yang diproses ada beberapa yang perlu diperhatikan seperti permodelan data dan pola aliran data.

\section{Modeling Data}

Permodelan data adalah pada inti dari desain database. Beberapa yang perlu diingat lagi adalah pendekatan Entity Relationship yang digunakan untuk mengklasifikasikan dan mmengorganisir data. Dalam usaha untuk membuat model maka yang dibutuhkan adalah entitas yang terdapat di dunia nyata dan bersifat penting kemudian diidentifikasi dan diklasifikasi. Entitas diklasifikasikan ke dalam sebuah tipe entitas yang memiliki kesamaan structural pada dunia nyata. Setelah diklasifikasikan maka entitas tersebut diberikan atribut yang sesuai dengan kegunaannya seperti entitas cutomer memiliki atribut nama, no id, dan kota begitu seterusnya. Kemudian entitas tersebut di dalam metamodel dari Entitry Relationship akan dihubungkan sesuai dengan relationship nya.

Untuk menggambarkan hubungan antar entitas tersebut dapat digunakan Entity Relationship Diagram. Setiap entitas tersebut digambarkan dengan bujur sangkar dan memiliki atribut yang digambarkan dengal lingkaran yang dihubungkan dengan garis dari entitas ke atribut. Kemudian masing - masing entitas tersebut dihubungkan dengan entitas lain menggunakan relationship yang digambrakan dengan wajik. 


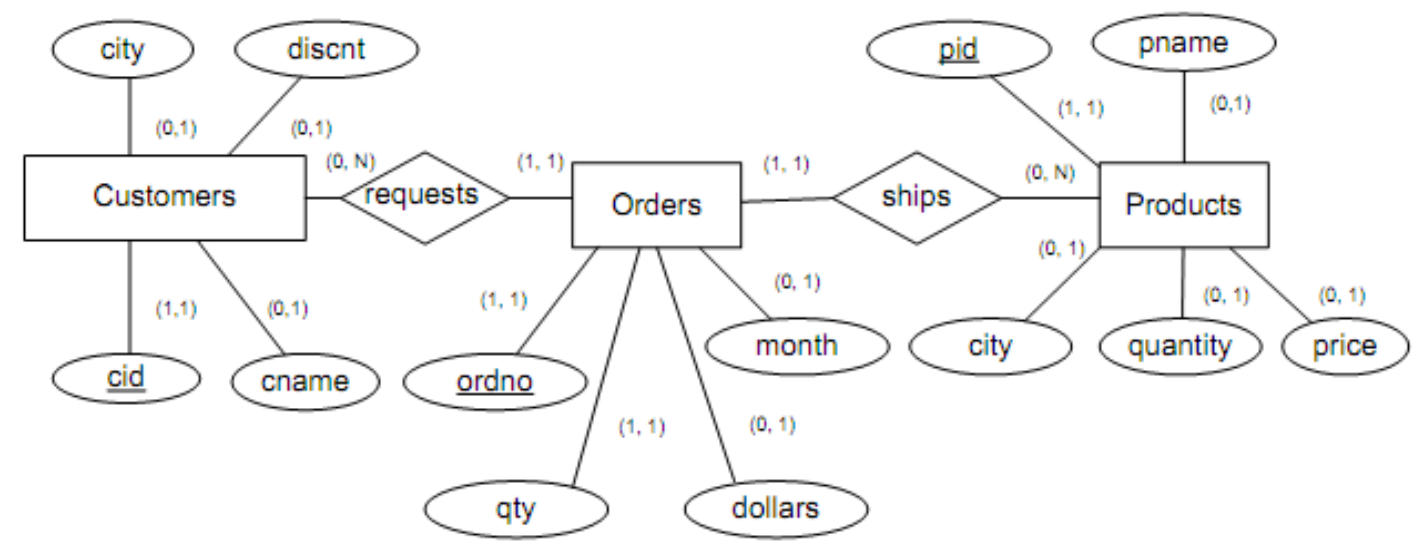

Setelah selesai membuat ERD tersebut maka dapat dilanjutkan dengan membuat Structured Query Language. Untuk dapat dibuat table dalam database.

\section{Workflow Data Pattern}

Work flow data pattern ini beguna untuk mejawab isu - isu yang berkembang dalam manajemen proses bisnis khususnya untuk mengorganisasikan keterhubungan antar data. Didalamnya berisikan bagaimana cara untuk menangani data dalam proses bisnis. Dimana data yang ada akan diorganisir dengan beberapa dimensi seperti

- Data visibility adalah bagaimana cara untuk agar data tersebut dapat dilihat oleh pihak yang tepat ada beberpaa yang harus diperhatikan dalam data visibility ini seperti :

- task data : data objek yang digunakan dalam aktivitas khusus, tidak bisa dilihat dalam aktivitas lain.

- Block data: data objek yang dapat dilihat oleh semua aktivitas yang diberikan oleh sebuah subproses

- Workflow data : sama seperti block data tetapi dalam mengaksesnya harus sesuai

\section{Modelling Organization}

Kordinasi adalah salah satu hal yang sangat pentinga dalam sebuah manajemen proses bisnis. Kordinasi ini dapat dilakukan dalam 
satu bagian atau departemen dalam organisasi atau bisa juga antar departemen yang berbeda, oleh karena itu maka permodelan dalam organisasi dirasa penting. Interaksi yang terjadi di dalam sebuah organisasi harus dibuat suatu aturan main. Interaksi juga dapat berupa pengiriman informasi di dalam struktur organisasi dimana proses bisnis akan dilakukan.

Prinsip umum dalam permodelan di organisasi adalah bagaimana mengatur sumbber daya seperti manusia yang bekerja dalam perusahaan dan sumber daya lain seperti gudang, truk, dan perlengkapan lain yang sekiranya dapat mendukung sebuah proses bisnis untuk mencapai tujuan organisasi.

Tugas yang diberikan kepada para partisipan dalam organisasi dapat diklasifikasikan dengan menggunakan resource pattern (pola sumber daya yang ada) seperti pembahasan pada bagian berikut.

\section{- Direct Allocation}

Seseorang dalam organisasi tidak hanya berperan sebagai orang yang duduk dalam sebuah posisi, tetapi orang tersebut dialokasikan untuk mengerjakan semua tugas yang menjadi tanggung jawabnya yang tergambar dalam model aktivitas.

- Role-Based Allocation

Adalah salah satu cara yang biasa digunakan untuk mengalokasikan pekerjaan kepada anggota dari organisasi. Berdasarkan pengertian dan pemahaman dari semua anggota yang menggunakan aturan khusus yang bagaimanapun juga memiliki fungsionalitas yang serupa, jadi semua anggota yang memiliki peran yang sama dapat menunjukkan sebuah kontribusi untuk suatu pekerjaan.

\section{- Defered Allocation}

Dalam deferred allocation keputusan tentang siapa yang berkewajiban melaksanakan sebuah instance aktivitas selalu dibuat saat suatu proses bisnis dikerjakan. Alokasi disini dikerjakan sebagai sebuah langkah yang berada diluar proses bisnis dan tidak terpengaruh oleh peran informasi.

\section{- Authorization}

Authorization mengalokasikan orang untuk mengerjakan instance aktivitas berdasarkan pada posisi mereka. Sebuah daftar posisi dituliskan satu persatu tentang tugas dari seseorang dimana mereka dapat mengerjakan suatu instance aktivitas.

\section{- Separations of Duties}

Separation of duties mengalokasikan rancangan yang bergantung dari alokasi yang berbeda untuk sebuah proses bisnis. Jadi untuk mengerjakan sebuah proses bisnis dapat dikerjakan oleh dua orang atau lebih yang nantinya pembagian dari tugas keduanya jelas direncanakan.

\section{- Case Handling}

Dalam case handling dialokasikan rancangan dimana beberapa aktivitas di dalam sebuah proses bisnis memerlukan sebuah pemahaman untuk semua kasus.

- History-Based Allocation 
Ide dasar dari history-based allocation adalah bahwa seseorang dapat dialokasikan untuk melakukan sebuah instance aktivitas yang didasarkan hasil dari pekerjaan yang dilakukan sebelumnya oleh orang sebelumnya. Jadi orang yang mengerjakan instance aktivitas yang sudah pernah dikerjakan sebelumnya akan diberikan pengalaman tentang apa saja yang terdahulu sudah dilakukan.

\section{- Organizational Allocation}

Dalam penggunaan organizational allocation ini, yang diperhatikan adalah posisi seseorang dalam organisasi bukan peran dari seseorang tersebut.

\section{Modeling Operation}

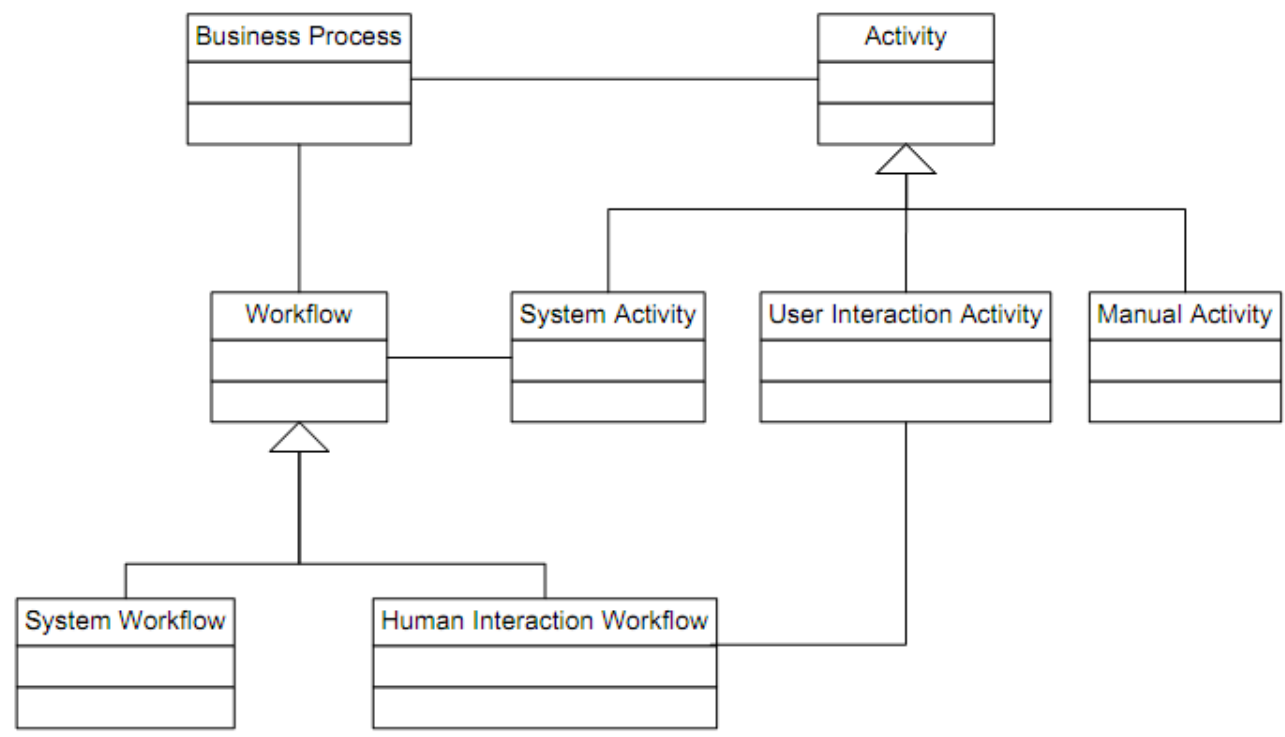

Aktivitas dapat dibedakan berdasarkan pada tingkatan dari dukungan system software. Klasifikasi dari aktivitas dalam proses bisnis tergantung kepada aktivitas system, aktivitas user interface, dan aktivitas manual. Untuk merekapitulasi, aktivitas system ditunjukkaan oleh system software tanpa adanya interaksi dari pengguna, aktivitas interaksi pengguna tersebut membutuhkan keterlibatan dari pengguna manusia dan aktivitas manual yang tidak melibatkan penggunaan dari system informasi.
Selama pembuatan aturan dari alur kerja manusia, pekerja berkemampuan khusus melakukan instance aktivitas. Dan ketika karyawan tersebut memulai pekerjaannya, maka respek dari program aplikasi dimulai, dan data input yang sudah dspesifikasikan dalam model proses akan dikirimkan kepada program aplikasi tersebut. Ketika karyawan tersebut selesai mengerjakan tugasnya, maka data output yang dibuat akan dikoleksi dan disimpan dalam parameter output. Nilai parameter ini kemudian dapat dikumpulkan ke dalam program aplikasi. Parameter tersebut dapat juga ditransfer oleh system manajemen proses bisnis untuk ditransfer ke aktivitas selanjutnya, sama 
seperti yang disebutkan dalam model proses bisnis.

Secara konseptual, level - level yang sama dari abstraksi digunakan untuk memodelkan perspektif operasional untuk memodelkan persepektif yang lainnya : pada tingkatan metamodel, terletak pada interface definition language. Interface definition language tersebut menjabarkan secara terperinci definisi dari interface pada tingkatan model. Pada level instance mengeksekusi kode software sudah dikatagorikan.

Pendekatan yang sesuai dengan memodelkan dari instances aktivitas berlangsung bagus, karena instance dari aktivitas dapat direalisasikan dengan mengeksekusi kode software. Dan biasanya hal tersebut sesuai dengan perspektif organisasi dimana seseorang digambarkan berada dalam instance sebuah level.

Dalam usaha untuk membangun fungsionalitas dari software tersebut, system manajemen proses bisnis memerlukan konsep dan teknologi untuk mengakses system ini. Perspektif operasional dari permodelan proses bisnis menyediakan informasi yang melengkapi sebuah system manajemen proses bisnis dengan informasi yang dibutuhkan untuk emenuhi fungsionalitas dari system aplikasi luar.

\section{BUSINESS PROCESS FLEXIBILITY}

Pencarian untuk fleksibilitas dapat dilakukan sebagai penggerak utama yang berada di balik manajemen proses bisnis, kedua hal pada level organisasional seperti proses bisnis strategis dan juga pada level operasional akan diinvestigasikan, dimana alur kerja interaksi manusia dan system adalah konsep yang penting untuk merealisasikan proses bisnis.

Pada hari ini lingkungan pasar yang dinamis, "different circumstances" akan dipengaruhi oleh perubahan dalam lingkungan pasar dari perusahaan. Semenjak suatu pruduk yang dihasilkan oleh perusahaan ke pasar akan dipengaruhi oleh proses bisnis, proses bisnis yang fleksibel adalah asset yang sangat penting untuk menjadi batas utama dengan perubahan pasar menggunakan cara yang efektif.

Pertama dari semuanya, fleksibilats dihasilkan oelh representasi ekplisit dari proses bisnis, karena adaptasi dari ekplisit, secara grafis proses bisnis yang sudah dispesfikasikan akan lebih mudah untuk diadaptasi dari pada prosedur organisasional yang tertulis atau aturan bisnis yang tertanam dalam kode software.

Secara tipikal dalam lingkungan alur kerja, seperti alur kerja system dan alur kerja interaksi manusia, system informasi dibutuhkan untuk membuat suatu aktivitas alur kerja.

\section{Explicit Process Representations}

System manajemen proses bisnis dibuat untuk mempersempit kesenjangan antara tujuan bisnis dan realiasi yang ada menggunakan pendekatan dari teknologi informasi. Jalan utama untuk menghasilkan fleksibilitas didasarkan pada representasi eksplisit dari proses bisnis pada level yang berbeda. 


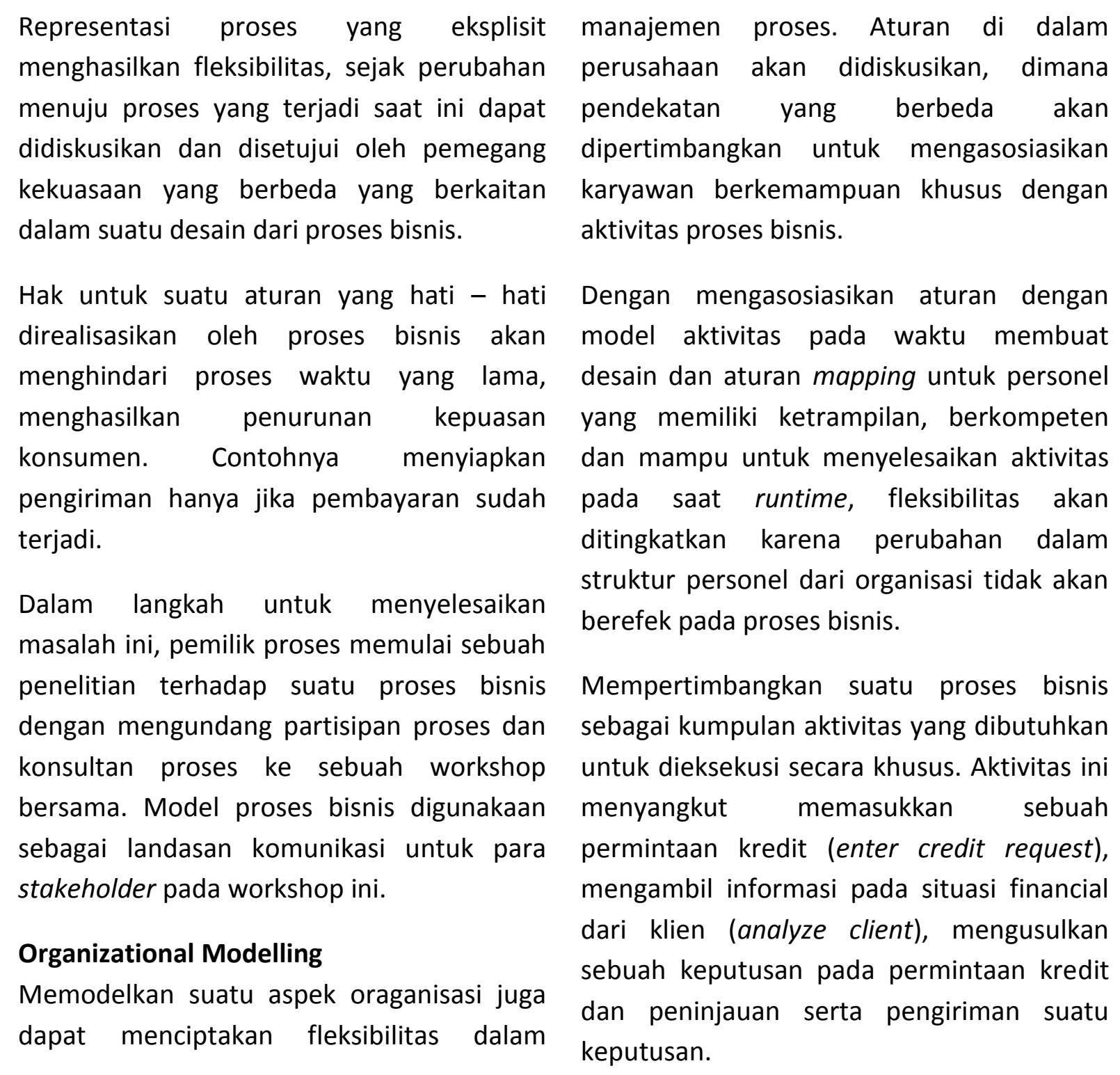

\section{ARCHITECTURE OF PROCESS EXECUTION ENVIRONMENTS}




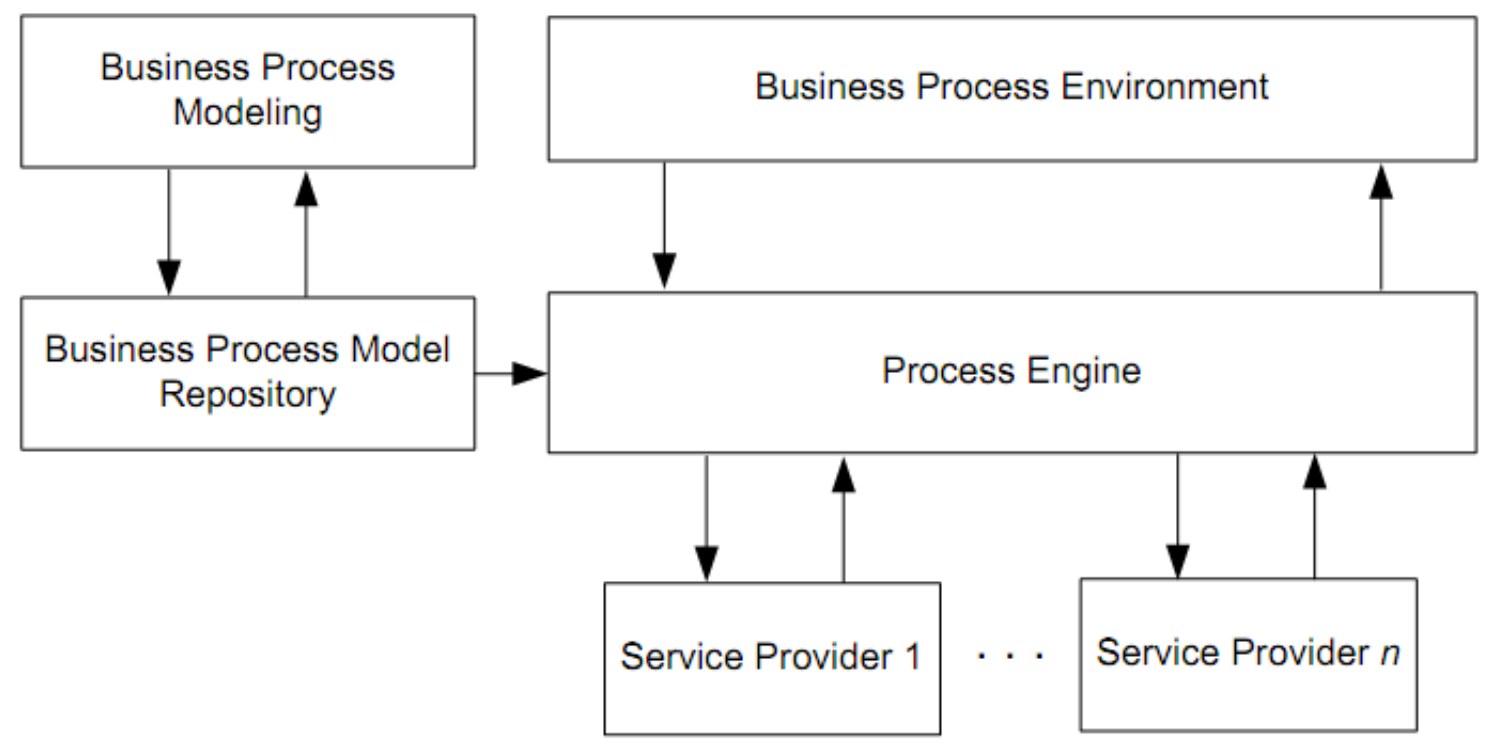

Gambar tersebut menggambarkan sebuah arsitektur model high-level dari manajemen proses bisnis yang berisikan komponen komponen dan hubungan. Penjelasan dari setiap komponen adalah sebagai berikut.

- Buniness process modeling : subsistem ini digunakan untuk menciptakan model proses bisnis, mengisi informasi pada setiap aktivitas, operasinya, dan struktur dari proses bisnis. Dan dapat direalisasikan menggunakan alat bantu business process modeling tools

- Business prcess environment : adalah sebuah pemicu yang berhubungan dengan instance proses yang berdasarkan kepada model.

- Business Model Repository : proses bisnis model repository adalah tempat dari model proses bisnis yang sudah dibuat oleh komponen process modeling.

- Process engine : adalah yang bertanggung jawab untuk menginstansiasi dan engontrol eksekusi dari proses bisnis. Yang juga merupakan inti dari sebuah sistem manajemen proses bisnis

- Service providers : merupakan asal dari service application yang merealisasikan aktivitas proses bisnis.

\section{REFERENSI}

FEA (2005), FEA Records Managemen Profiles verion 1.0, Http://www.archives.gov/records$\underline{\mathrm{mgmt} / \mathrm{pdf} / \mathrm{rm} \text {-profile.pdf }}$

Mathias Weske (juli 2007), Business Process Management concepts Language and Management

Thomas Dufresne \& James Martin (2003), Process Modelling for E-Business 